\section{Dr. C. H. O'Donoghue}

DR. C. H. O'DONOGHUE has been appointed to the chair of zoology in the University of Reading in succession to Prof. F. J. Cole (see Nature of March 4, p. 368). After graduating with first-class honours in zoology and physiology from King's College, London, he was appointed lecturer in zoology at University College. He obtained the D.Sc. degree in 1912, was awarded a Beit Memorial Scholarship for research and spent six months studying at Freiburg under Prof. F. Doflein. In 1918 he went to Canada as professor of zoology in the University of Manitoba, and in 1923 acted as director of the Marine Biological Station at Nanaimo, Vancouver Island. For two terms he was visiting professor at Stanford University, California. He was also appointed by the Canadian Government for two years as head of a scientific expedition to Jasper Park in the Rocky Mountains. As a member of the Research Committee of the Biological Board of Canada, he helped to establish the Prince Rupert and Cultus. Lake Stations. In 1927 he returned to Great Britain at the invitation of the late Prof. J. H. Ashworth, to become senior lecturer and later reader in zoology in the University of Edinburgh. In 1932 ho was awarded the Neill Prize of the Royal Society of Edinburgh, and he was president of the Royal Physical Society of Edinburgh in 1933. His research covers a wide field, but is chiefly concerned with the taxonomy of the Bryozoa and Nudibranchia, and with vertebrate anatomy, physiology and embryology.

\section{Prof. M. Leclerc du Sablon}

Congratulations are to bo extended to Prof. Mathieu Leclerc du Sablon, who attains his eightieth birthday on March 25. Prof. Leclerc du Sablon is probably the last living member of the famous group of French botanists who at the end of the nineteenth century made very important contributions to the study of plant anatorny. From 1883 until 1890 he was working in Paris at the Ecole Normale Supérioure, and later at the Natural History Museum under Van Tieghem, his father-in-law and teacher. During this period he produced a serios of important papers on various subjects in some of which are facts now taught to every student of elementary botany. His studies on the dehiscence mechanisms of anthers in the flowering plants and of the sporangia in the Archegoniatæ are especially noteworthy; he was the first to discover the mechanism of the annulus in the fern sporangium. Other important contributions were papers on the structure and physiology of tendrils, on the haustoria of parasitic flowering plants, on the development and comparative structure of the sporophytes of Liverworts, and on the develop. ment of the vascular system in young fern plants. In 1890 he was appointed professor of botany in the University of Toulouse, a post which he held for thirty years. His extensive knowledge of plants found oxpression in the "Cours de Botanique", a large text-book writton in collaboration with Gaston Bonnier, his brother-in-law and former colleague. The first part of this work appeared in 1901; but it was not completed until 1933 when, after the death of Bonnier, the last part dealing with plant physiology was published. His activities have covered an $\Theta x$ ceptionally wide field, and his influence on the development of botany, especially in France, has been very considerable.

\section{Archæological Studies in France}

Prof. H. V. Vallois, professor in the Faculty of Medicine of the University of Toulouse, has been appointed professor of prehistoric anthropology in the Institut de Paléontologie humaine of the University of Paris. Prof. Vallois, who has long been recognized as standing in the front rank of authorities in France on human palæontology, has been in charge of the anthropological laboratory for practical studies of the Ecole des Hautes Etudes in Paris since 1937, and is senior editor of the periodical L'Anthropologie. He took up his duties at the Institut at the beginning of the current semester, and is delivering a course of lectures on the general principles of human palæontology and the prehominids. A course of lectures on prehistoric ethnography is also being delivered concurrently by the Abbé Breuil. A new department has been formed in the Ecole des Hautes Etudes for the study of geology with special reference to the origin of man. The first director of the department will be P. Teilhard de Chardin, who during his prolonged residence in the Far East has made numerous and important contributions to the study of the palæontology and pre-history of China and south-eastern Asia. It will be remembered that the first discovery of palæolithic implements in China was due to Teilhard de Chardin, while his studies of the fossil fauna of Choukoution is the basis for the dating of Peking man. He contributes to the current issue of L'Anthropologie $(48,5-6 ; 1938)$ notes on the human palæontology of southern Asia, summarizing the results of his observations in Burma, Malaya, Java and Indo-China, when accompanying Dr. Hellmut de Terra on his recent geological and archæological survey in the Far East, supplementary to his investigations in India (see NATURE, 143,$275 ; 1938$ ).

\section{German Activities in Central Europe}

DURING the past fortnight, the State of Czechoslovakia has been forcibly broken up and a large part absorbed into the "(rreat German Reich" as the "Protectorate of Bohemia and Moravia". In the account of Czochoslovakia's contributions to science which appeared in NATURE of November 26, 1938, pp. 942-44, the hope was expressed that the scientific and cultural development of the Czechs would still be possible after their territory had been drastically curtailed by the Munich Agreement, and that they would continue to make contributions to the advancement of scientific knowledge and take a share in its application to the welfare of mankind. This hope was qualified by the anxiety then felt for those men of science and learning whom the impovorished State might not be able to support, and it is gratifying to know that, until recontly, indeed 